\title{
Analysis of Introduction to Development of Mathematics Learning Devices Based on Professional Competence in Vocational School of X in Field of Tourism
}

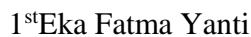 \\ Mathematics Department \\ Universitas Negeri Padang \\ Padang, Indonesia \\ ekafatmayanti87@gmail.com
}

\author{
$2^{\text {nd }}$ Armiati \\ Mathematics Department \\ Universitas Negeri Padang \\ Padang, Indonesia \\ armiati@fmipa.unp.ac.id
}

\author{
$3^{\text {rd }}$ Ahmad Fauzi \\ Physics Department \\ Universitas Negeri Padang \\ Padang, Indonesia
}

\begin{abstract}
This study discusses the development of professional competency-based mathematics learning tools in hospitality expertise programs and tourism services in class $\mathrm{X}$ Vocational High Schools (SMK). The tools developed are in the form of Learning Implementation Plans (RPP) and Student Worksheets (LKPD). The development models used in this study is a Plomp model consisting of Preliminary Research, Prototyping Phase, and Assessment Phase. But in this study, the stages of preliminary research will be discussed. Vocational students in hospitality expertise programs and tourism services. Based on problems obtained from observations made in Vocational Schools. found serious problems faced by vocational students including: (1) general teaching and learning experiences, (2) learning processes that are less attractive to students, (3) experience in the class result of teacher's treatment, $(4)$ perception that is formed by failure to learn mathematics. They regard mathematics as not taking an important role in exploring vocational competencies and in the areas of expertise that students choose. The purpose of this research is to analyze the learning problems that occur in Vocational Schools. The results of this study indicate that: (1) it is necessary to improve the mathematics learning tools used so far, (2) the devices that will be developed using the context of tourism expertise problems, (3) the learning tools that will be developed are professional competency-based learning tools.
\end{abstract}

Keywords-Preliminary Analysis, Mathematics Learning Devices, Professional Vocational Competencies

\section{INTRODUCTION}

Mathematical problem-solving ability is one of the important goals in learning mathematics. Having problemsolving ability helps students to think analytically in making the decision and to improve mathematical problem-solving ability in facing the new situation [1]. In fact, the level of problem-solving ability of Indonesian students is still under expectation in solving non-routine problems [2]. The highest score in International is $66 \%$ participants of TIMSS that can solve the problem successfully. But, for Indonesia only $11 \%$ participants of TIMSS that can solve the problem successfully [3].

The implementation of the 2013 curriculum emphasizes the efforts of teachers to provide motivation and skills improvement. This is also stated in the [1] concerning Curriculum Structure. The 2013 curriculum aims to prepare
Indonesian people to have the ability to live as personal citizens who are faithful, productive, creative, innovative, and affective and able to contribute to world life, nation, state, and world civilization. In connection with the 2013 SMK Curriculum, graduates aim to increase intelligence, knowledge, personality, noble character, and the skills to live independently and follow further education in accordance with their vocational skills. This shows that vocational schools as institutions must prepare graduates in a comprehensive and inclusive manner, helping students to develop their educational achievements meaningfully based on their potential so that it is beneficial for the community where they live after completing education.

In connection with the above behavior, Purnomo [2] that there are eight main behavioral components that must be possessed by students or graduates of vocational school namely; (1) Having strong and broad basic skills that enable development and adjustment according to the development of science and technology; (2) Able to collect, analyze, and use data and information, (3) Able to communicate ideas and information; (4) Able to plan to organize activities, (5) Able to work together in work groups, (6) Able to solve problems, (7) Logical thinking, and able to use mathematical techniques; (8) Mastering global communication (English).

Jatmoko [3] suggests that Vocational Schools (SMKs) are educational institutions that have been absorbed by the world of work. In vocational materials, applicative theories and practices that have been given since the first entry with the hope that graduates have the competence in accordance with the needs of the workforce. Thus the vocational school students are taught and directed to be able to plunge into the world of work on a professional competency that engages in their field of expertise.

Spencer [4] states that "competence exists in someone who is related to criteria related to effectiveness or high performance in a particular job or situation." For that reason, vocational schools not only conduct education in accordance with the world of work today. Departing from the above, vocational school students must be able to complete all subjects and training programs according to the time specified. Based on the structure of the Mathematics Vocational High School curriculum it is itself one of the compulsory subjects in the group that is must be studied. 
The purpose of learning mathematics according to the National Council of Teachers of Mathematics in Hamida [5] is (1) learning to communicate (mathematical communication), (2) learning to reason (mathematical reasoning), (3) learning to solve problems (mathematical problem solving), (4) learning to associate ideas (mathematical connection), (5) the formation of a positive attitude towards mathematics ( positive attitude toward mathematics) . Correspondingly in the Minister of National Education [6] concerning the Mathematics Subject Standards for teaching vocational students:

1. Understanding mathematical concepts, explaining the interrelationship between concepts, and applying concepts o $r$ algorithms flexibly, accurately, efficiently and precisely in problemsolving;

2. Using reasoning on patterns and traits, manipulating, mathematics in generalizing, compiling evidence, or explaining mathematical ideas and statements;

3. Solve problems that include the ability to understand problems, design mathematical models, complete models, and interpret solutions obtained;

4. Communicate ideas with symbols, tables, diagrams, or other media to clarify circumstances or problems;

5. Having respect for the usefulness of mathematics in life, namely having curiosity, attention, and interest in learning mathematics, as well as a tenacious attitude and confidence in problem-solving;

6. Having attitudes and behaviors that are in accordance with the values in mathematics and learning, such as principles, consistency, upholding agreements, tolerance, respecting opinions of others, polite, democratic, resilient, resilient, creative, appreciating nationality (environmental context), cooperation, fair, honest, thorough, careful, flexible and open, have a willingness to share feelings with others;

7. Conduct motoric activities that use mathematical knowledge;

8. Using simple teaching aids and technology results to carry out mathematical activities. These skills or abilities are closely related, one strengthens as well as requires the other

To achieve the goal of vocational learning mathematics is inseparable from the role of teachers who will interact directly to carry out the learning process in the classroom. Learning objectives can be achieved if teachers plan and implement effective and efficient learning. Parjono in Orlich [7] states "Planning is more than about what you want to accomplish. You think about the details, such as who does what, when, for opportunities will be created for effective student learning. "

The Learning Implementation Plan (RPP) contains an outline of activities that will be carried out by the teacher and students during the learning process. Preparation of the RPP begins with the identification of competencies, selection of strategies, methods, and evaluations. The achievement of learning goals requires a learning strategy, the teacher's effort in creating an environmental system that allows teaching and learning to be implemented so that learning objectives that have been formulated can be successful and effective (Hardini and Puspitasari, 2012).
Based on the research of Armiati [8] Vocational Schools were less desirable, namely the learning devices and teaching materials used by teachers were general in nature, namely learning devices and teaching materials. devices and teaching materials used in high school.

Students' negative attitudes toward mathematics will also be influenced by their experience when learning mathematics in elementary, middle and high school. But as a vocational teacher, there must be an effort to eliminate the negative attitudes of the students by little, so that students have a positive attitude towards mathematics. This also happened for several vocational schools in Padang Pariaman District. Information that is received at the selection stage of new student admissions for each school that conducts interviews with applicants / prospective students. Each vocational program conducts an interview test with students who enroll in the school. In general, prospective students take a study program based on the will of themselves

Furthermore, based on the experience of teaching at the State Vocational High School 1 in Tobuk Gadang. There are several important problems faced by mathematics teachers in vocational schools. Especially those who have implemented the 2013 curriculum in schools, as for the problems are:

1. The RPP is designed by the teacher is the same for all skills programs in Vocational Schools. In particular, the RPP is used in hospitality expertise and travel businesses are similar to computer engineering and informatics, automotive engineering and culinary expertise programs.

2. The learning process does not pay attention to the characteristics of students in each skill program.

3. The materials and exercises provided because there is no available Student Worksheet (LKPD).

Based on the above problems, improvements are needed to the learning tools (RPP) and the provision of LKPD. The RPP is an important learning tool because the teacher has guidelines in carrying out the learning process because RPP is arranged so that the learning process can run systematically, effectively, fun. Furthermore, with the availability of LKPD, the teacher can use the learning process run well. The availability of LKPD provides opportunities for students to play an active role in every learning process, or in other words students become the subject of learning. Because LKPD provides material in a concise and systematic manner so that students can easily contradict the information conveyed, and LKPD diverse problems so as to improve student experience to solve various problems, both problems, and abstract problems.

Based on research conducted by Hestu Tansil entitled "Development device Learning Mathematics Based on Competence Profession in Vocational Fields Expertise Technology Information and Communication "is obtained conclusion that device learning that was developed valid (RPP 3.49, LKPD 3.68), practical (RPP 86.16\%, LKPD $86.52 \%$ ), and effective.

In relation with research conducted by Hestu Tansil then device that will be developed on research this is device learning (RPP) and The LKPD based on competence profession on field expertise tourism. Devise this designed by the researcher to get it used by a math teacher along with it participants students in vocational schools, especially skills programs hospitality and business travel. Device RPP and LKPD learning are made based on competence profession considering that SMK has many competence expertise and participants student more many spend his days with theory 
and practice corresponding competence his expertise. The device this made with associate material mathematics is taught with situation real or related with competence the expertise of the participants the disk.

\section{METHODS}

Research conducted on research this is research development. Research development is method The research to develop or validate products used in the education process and learning. The research model used in research this is development model Plomp. Plomp [9] Development model Plomp consists of from three stage, that is phase investigation early (preliminary research), phase development or prototype manufacture (development or prototyping stage), and phase judging (assessment stage). On phase invest early (Preliminary research) conducted is done analysis needs, analysis curriculum, analysis concept, and analysis participants student and teacher. The analysis that does for collect data, analyze, and identify problems that occur during the learning process. this does with the aim for determining alternative solutions and specification products required from problems found.

\section{RESULTS AND DISCUSSION}

The stage of needs analysis is carried out gathering information about the problems contained in the learning and existing mathematics learning tools. Information gathering is carried out through interviews with teachers, observing the implementation of learning and analyzing existing learning tools (RPP and LKPD). This activity was carried out in class $X$ SMK Negeri 1 Sintuk Toboh Gadang in expertise hospitality programs and travel business.

Interviews with teachers are carried out informally. This interview relates to students in learning and subject matter that is considered difficult for students. Based on the results of interviews Obtained in general has not been optimal learning to makeup Become saturated and bored students in mathematics learning and learning is monotonous. When given a variety of practice questions students cannot work on it and follow the work of highly skilled students on the grounds that they do not understand the material described by the teacher so they will wait for the discussion of the questions from the teacher.

Furthermore, based on the experience of researchers during teaching at SMK 1 Sintuk Toboh Disease in carrying out the learning process using the same RPP design for each different skill program. While for different skills programs, of course, they have different characteristics and problems. Other problems are the availability of the Student Worksheet.

Based on the findings from the needs analysis, need to be making improvements. These improvements need to be done at the design stage of the learning process. The learning process is made by paying attention to the characteristics and problems that exist in each skill program. This can be done by analyzing the productive competencies of expertise programs and travel business with mathematics learning competencies.

In the analysis phase of this curriculum, researchers reviewed the 2013 revised curriculum for mathematics and productive subjects used in vocational schools. This curriculum analysis is conducted to see the suitability of Core Competencies (KI) and Basic Competencies (KD), Indicators of Achievement of Competence (GPA) and learning objectives in mathematics material in Vocational
High Schools. Based on Kepmendikbud [10] concerning the secondary structure of education in the Basic Competencies (KD) of mathematics in Vocational Schools are divided into two parts, namely KD technology mathematics and nontechnology Mathematics KD.

Given the conditions and time of the researcher, the curriculum analysis in this study was carried out for KD nontechnology in the field of tourism for hospitality expertise and business travel in the odd semester X class. The basic math competencies of class $\mathrm{X}$ are determined by the Ministry of Education and Culture are compiled through the MGMP of Mathematical Vocational High School. The MGMP Vocational Education Program used in analyzing the curriculum in this study. Considering that the learning tools that will be developed are mathematics learning tools based on professional competencies, the researcher also needs to analyze any mathematics that is related to the professional competency in the hospitality program and the tourist travel business of class X students.

Mathematical material taught in class X Non-technical Vocational High School on odd semester based on Kepmendikbud 130 / D / KEP / KR / 2017 concerning Vocational Education Curriculum Structure is (1) Rank number, Root form, Logarithm, (2) Absolute Value, (3) SPLDV, (4) Linear Programs, (5) Arithmetic Rows and Series, (6) Geometry Rows and Series, and (7) Growth, Decay, Interest and Annuities. In hospitality expertise programs in the form of (1) Tourism, (2) Hospitality Industry, (3) Front Office, (4) Housekeeping, (5) Laundry, (6) Food and Bavarian and Travel Business in the form of: (1) Booking and Flight Rate Calculation, (2) Tourism Travel Planning and Management, (3) Guidance Travel Tour, (3) Mice Management.

Based on the curriculum analysis conducted at SMK Negeri 1 Sintuk Toboh Gadang, SMK Negeri 2 Pariaman as well as interviews conducted on teachers who participated in MGMP activities in Padang- Pariaman District that the mathematics material given in the non-technical grade $X$ vocational school in odd semester was (1 ) Rank number, Root form, Logarithm, (2) Absolute Value, (3) SPLDV, (4) Linear Program, (5) Arithmetic Series and Series, (6) Geometry Series and Series. But the material of growth, decay, interest, and annuity is taught in even semesters as a continuation of material from the odd semester. Based on the results of the curriculum analysis conducted, KD material in class X SMK in the field of tourism expertise will be developed in the odd semester can be seen in Table 1 below:

TABLE I. Results KI ANALysis, KD MATERial Mathematics The 2013 CURRICULUM IN THE X SEMESTER OF TECHNOLOGY SMK

\begin{tabular}{|c|c|}
\hline Kom & \\
\hline \multirow{6}{*}{$\begin{array}{lr}\text { Memahami, } & \text { menerapkan, } \\
\text { menganalisis, dan } \\
\text { mengevaluasi } \\
\text { pengetahuan } \\
\text { konseptual, operasional dasar, } \\
\text { dan metakognitif sesuai dengan } \\
\text { bidang dan lingkup kajian } \\
\text { matematika pada tingkat teknis, } \\
\text { spesifik, detil, dan kompleks, } \\
\text { berkenaan dengan ilmu } \\
\text { pengetahuan, teknologi, seni, } \\
\text { budaya, dan humaniora dalam } \\
\text { konteks pengembangan potensi } \\
\text { diri sebagai bagian dari } \\
\text { keluarga, sekolah, dunia kerja, } \\
\text { warga masyarakat nasional, } \\
\text { regional, dan internasional. }\end{array}$} & $\begin{array}{l}\text { Menerapkan konsep bilangan } \\
\text { berpangkat, bentuk akar, dan logaritma } \\
\text { dalam menyelesaikan masalah. }\end{array}$ \\
\hline & $\begin{array}{l}\text { Menerapkan persamaan } \\
\text { pertidaksamaan nilai mutlak } \\
\text { linear satu variabel. }\end{array}$ \\
\hline & $\begin{array}{l}\text { akan nilai variabel pada sistim } \\
\text { lan linear dua variabel dalam } \\
\text { kontekstual. }\end{array}$ \\
\hline & $\begin{array}{l}\text { Menentukan nilai maksimum dan } \\
\text { minimum permasalahan kontekstual } \\
\text { yang berkaitan dengan program linear } \\
\text { dua variabel. }\end{array}$ \\
\hline & $\begin{array}{l}\text { Menganalisis } \\
\text { aritmatika. }\end{array}$ \\
\hline & $\begin{array}{l}\text { Menganalisis } \\
\text { geometri. }\end{array}$ \\
\hline
\end{tabular}


After agreed upon Competence Basic the math that will be learned during semester one for class $\mathrm{X}$ on field tourism with expertise programs hospitality and business travel comprising travel from six KD. Next, do analysis from KD eye lesson mathematics with $\mathrm{KD}$ eyes lesson on expertise programs hospitality and business travel. Results analysis that obtained $5 \mathrm{KD}$ in the expertise program hospitality and business travel tour in the learning process could be applied with KD eyes lesson mathematics. KD eye application lesson mathematics with a KD expertise program could be seen on table 2 .

TABLE II. COMPETENCE BASIC IN LESSON MATHEMATICS AND UBJECTS PRODUCTIVE CLASS X VOCATIONAL SCHOOL IN THE EXPERTISE PROGRAM HOSPITALITY AND BUSINESS TRAVEL ODD SEMESTER TOURISM YEAR 2018-19 LESSONS

\begin{tabular}{|c|c|}
\hline Mata PelajaranMatematika & Mata PelajaranProduktif \\
\hline $\begin{array}{l}\text { Menerapkan persamaan dan } \\
\text { pertidaksamaan nilai mutlak bentuk } \\
\text { linear satu variabel }\end{array}$ & $\begin{array}{l}\text { 3.2. Menganalisis perencanaan } \\
\text { perjalanan wisata }\end{array}$ \\
\hline $\begin{array}{l}\text { 4.2. Menyelesaikan masalah yang } \\
\text { berkaitan dengan persamaan dan } \\
\text { pertidaksamaan nilai mutlak bentuk } \\
\text { linear satuvariabel }\end{array}$ & $\begin{array}{l}\text { 4.2. Memberikan informasi } \\
\text { perjalanan wisata }\end{array}$ \\
\hline 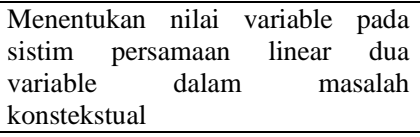 & $\begin{array}{l}\text { 3.3.Menganalisis modal dasar } \\
\text { pengembangan pariwisata }\end{array}$ \\
\hline $\begin{array}{l}\text { 4.3. Menyajikan penyelesaian } \\
\text { masalah sistim persamaan linear } \\
\text { dua variabel }\end{array}$ & $\begin{array}{l}\text { 4.3. Membuat perancangan modal } \\
\text { dasar pengembangan pariwisata }\end{array}$ \\
\hline $\begin{array}{l}\text { Menentukan nilai maksimum dan } \\
\text { minimum permasalahan } \\
\text { kontekstual yang berkaitan dengan } \\
\text { program linear dua variabel }\end{array}$ & $\begin{array}{lr}\text { 3.4.Menganalisis } & \text { pengaruh } \\
\text { industry perhotelan } & \text { terhadap } \\
\text { peningkatan SDM } & \end{array}$ \\
\hline $\begin{array}{l}\text { 4.4.Menyajikan penyelesaian } \\
\text { masalah kontekstual yang berkaitan } \\
\text { dengan program linear dua variabel }\end{array}$ & $\begin{array}{ll}\text { 4.4.Menunjukkan } & \text { pengaruh } \\
\text { industry perhotelan } & \text { terhadap } \\
\text { pengembangan SDM } & \\
\end{array}$ \\
\hline $\begin{array}{l}\text { Menganalisis barisan dan deret } \\
\text { aritmatika }\end{array}$ & 3.5.Menganalisis penataan ruang \\
\hline $\begin{array}{l}\text { 4.5. Menyelesaiakan masalah } \\
\text { kontekstual yang berkaitan dengan } \\
\text { barisan dan deret aritmatika }\end{array}$ & 4.5.Melakukan penataan ruang \\
\hline $\begin{array}{l}\begin{array}{l}\text { Menganalisis barisan dan deret } \\
\text { geometri }\end{array} \\
\end{array}$ & $\begin{array}{l}\text { 3.6.Menganalisis informasi } \\
\text { produk layanan industry MICE }\end{array}$ \\
\hline $\begin{array}{l}\text { 4.6. Menyelesaiakan masalah yang } \\
\text { berkaitan dengan barisan dan deret } \\
\text { geometri }\end{array}$ & $\begin{array}{l}\text { 4.6.Mengakses informasi produk } \\
\text { dan layanan industry MICE }\end{array}$ \\
\hline
\end{tabular}

After obtaining KD in mathematics and productive subjects, then the basic competencies are translated into indicators of achievement and learning objectives in mathematics and productive subjects that can be applied in mathematics because not all students can be applied with mathematics.

In the analysis phase of this concept, the researcher determines the content of mathematical material that will be studied in class X SMK in the field of tourism expertise. In addition, from the content of the material specified, the researcher also determines the problems of the professional competency of students in expertise hospitality programs and travel business. The material learned in class $\mathrm{X}$ of the Vocational School in the odd semester of the 2018/2019 Learning Year is the material of Number, Root Shape, Logarithm, Absolute Value, SPLDV, Linear Program, Line and Series.

The analysis of students and teachers conducted at SMK 1 Sintuk Toboh Gadang aims to find out the characteristics of students, which include: cognitive level, age, learning style and motivation for learning. Uno (2007: 27) said that "identifying the characteristics of students is very necessary to know the quality of individuals to be used as a guide in learning". To study the characteristics of students in class X SMK, observations were made during learning and interviews with several students.

Based on observations that have been made in the learning process so far, it is generally known that students' learning methods are (1) Students like LKPD or books with unique letters and bright colors and images (2) Application of detailed learning stages and clearly, interspersed with the application of a learning process that can eliminate the boredom of students in learning. (3) Learners prefer to discuss with a friend of mine. (4) students are compared to mathematics students (5) students prefer to work in groups rather than individuals.

Based on the characters found from the results of the study, the researchers feel the need to develop the learning tools. Professional competence-based learning devices are learning that can help students in constructing their knowledge through the findings made. The use of LKPD in learning will make students focus and concentrate to fill it.

\section{CONCLUSION}

Learning by using professional competency-based learning tools in class X Vocational School in the hospitality expertise program and tourism business trip that will be developed only reaches the preliminary research stage. The Plomp model used in this study three stages, namely preliminary research, prototyping phase, and assessment phase, which was very helpful in developing professional learning-based mathematics learning tools.

With the RPP based on professional competencies to be developed, it is easier for teachers to teach mathematics to vocational students in the field of tourism expertise. This is expected to increase the motivation and interest of students to learn mathematics. Student Participant Worksheets (LKPD) based on professional competencies contain activities of students who refer to improving students' problem-solving abilities. In LKPD, based on professional competencies, the context of the problem of students' areas of expertise can be solved using mathematical models. Through the context of the problem in the field of tourism expertise, it is expected that students will be more curious and more interested in solving the given problem.

\section{REFERENCES}

[1] Permendiknas, Bimtek Penyelenggara Instruktur dan Pelatihan GS Kurikulum 2013: Sprektum Keahlian Pendidikan Menengah Kejuruan, Direktorat Pembinaan SMK: Kemdikbud 2017, 2017.

[2] Purnomo Edy, et al, Evaluasi Hasil Belajar Dalam Implementasi Kurikilum Berbasis Kompetensi di SMK, FT: UNY. Cakrwala Pendidikan, Juni 2005, Th.XXIV, No.2, 2005.

[3] Jatmoko. D, "Relevansi Kurikulum SMK Kompetensi Keahlian Kendaraan Ringan Terhadap Kebutuhan Dunia Industri di kabupaten Sleman", Jurnal Pendidikan Vokasi, vol. 3, 2013.

[4] Spencer, M. Signe \& Spencer, M, Lyle, Competence at Work: Models for Superrior Performance, John Wily \& Son, Inc, New York, USA, 1993.

[5] Hamidah. Mida Tsamrotul, et al, "Peningkatan Kemampuan Komunikasi Matematik Peserta Didik Melalui Model Learning Cycle 5E (LC)dengan Pendekatan Scientifik", Jurnal Penelitian Pendidikan dan Pengajaran Matematika, vol. 3, pp 137-144, 2017. 
[6] Peraturan Menteri Pendidikan dan Kebudayaan Republik Indonesia Nomor 58 Tahun 2014 tentang Standar Proses Pendidikan Dasar dan Menengah.

[7] Pardjono, et al, "Implementasi Pembelajaran Berbasis Kompetensi do SMK", PPs UNY, Cakrawala Pendidikan, Juni 2012, Th. XXXI, No.2, 2012.

[8] Armiati, "Pengembangan Modul Matematika Berbasis Kompetensi Profesi Pada Sekolah Menengah Kejuruan Teknologi", Dirjen PT Depdiknas. Penelitian Hibah Bersaing: FMIPA-UNP, 2008.

[9] Plomp, T \& Nievenn N, Educational Design Research-Part A: An Introduction, Enschede: Netherland Institute for Curriculum Development (SLO) PQ4R Strategy Accompanied by Refutation Text Reading, 2013.

[10] Kemendikbud 130 D/KEP, Struktur Kurikulum Pendidikan Menengah Kejuruan, 2017. 